DOI 10.14746/ssp.2019.1.10

Maciej BACHRYJ-KRZYWAŹNIA

Uniwersytet Wrocławski

ORCID: 0000-0002-8072-9488

\title{
Dedykowany storytelling - psychologiczne przesłanki perswazyjnej efektywności narracyjnego marketingu politycznego
}

Streszczenie: Teoretycy i praktycy storytellingu koncentrują się zazwyczaj na formalnych właściwościach przekazu, upatrując klucza do jego perswazyjnej skuteczności w realizacji strukturalnych cech opowiadania. Niniejszy artykuł kładzie natomiast nacisk na poznawczy aspekt relacji komunikat-odbiorca, upatrując w nim ważnego czynnika determinującego siłę perswazyjnego oddziaływania storytellingu. W pierwszej części tekst analizuje psychologiczne przesłanki skuteczności perswazyjnej narracyjnego komunikatu. Część kolejna stanowi teoretyczną propozycję w jaki sposób zwiększyć skuteczność jego oddziaływania, uwzględniając budowę, właściwości i funkcje schematów poznawczych oraz w oparciu o model poznawczych reakcji na perswazję.

Słowa kluczowe: storytelling, marketing narracyjny, marketing polityczny, perswazja

\section{Wstęp - cel artykułu i ustalenia terminologiczne}

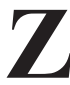
asadniczym celem niniejszego artykułu jest zaproponowanie teoretycznego modelu dedykowanego storytelingu politycznego. Realizacja tego celu będzie przebiegała dwuetapowo. Etap pierwszy, będzie polegał na rekonstrukcji i krytycznym odniesieniu się do obecnych w literaturze modeli storytellingu, bazujących zdaniem autora na formalnych aspektach komunikatu narracyjnego i koncepcji biernego poznawczo odbiorcy. W etapie drugim, przedstawione zostaną teoretyczne podstawy przezwyciężenia zidentyfikowanych słabości tych modeli i zwiększenia tym samym efektywności perswazyjnego oddziaływania marketingu narracyjnego. $\mathrm{W}$ tym celu zostanie przywołane instrumentarium pojęciowe z zakresu nurtu poznawczego psychologii społecznej, a konkretnie teoria schematów poznawczych i tzw. modelu poznawczych reakcji na perswazję. Umożliwi to sformułowanie ogólnych dyrektyw odnośnie praktycznych aspektów kon- 
struowania komunikatu storytellingowego, w celu jego precyzyjniejszego dopasowania (dedykowania) do potrzeb poszczególnych odbiorców oraz ich segmentacji jako tzw. wspólnot narracyjnych.

Marketing i storytelling, dwa pojęcia kluczowe w kontekście niniejszego artykułu, będąc dyskutowanymi w literaturze naukowej i fachowej już czas jakiś, zdążyły obrosnąć znaczeniami i niuansami, których pełne zreferowanie z pewnością przekracza objętość jednego artykułu. W przypadku kategorii „storytelling”, młodszego, a z racji multidyscyplinarnych konotacji związanej z nim kategorii narracji, zadanie to wydaje się szczególnie złożone. Ponieważ jednak celem tego artykułu nie jest zabieranie głosu w debacie o tym jaki jest zakres pojęciowy obu terminów, poprzestanę w tej materii jedynie na krótkim wprowadzeniu i deklaracji stanowiska przyjętego na potrzeby niniejszego artykułu.

Marketing, u swego zarania pojęcie związane przede wszystkim z działalnością gospodarczą, wraz z każdą kolejną teoretyczną i praktyczną innowacją, podlegało licznym definicyjnym transformacjom (Wiszniowski, 2002, s. 46-49; 2000, s. 11-16; Mazur 2004, s. 14-17). Przeniesienie reguł postępowania marketingowego na grunt polityki, związane z postrzeganiem demokratycznej przestrzeni politycznej jako swoistego rynku idei, osobowości i organizacji, konkurujących o uznanie konsumentów-wyborców, doprowadziło do wyodrębnienia marketingu politycznego, jako mającego odmienną od marketingu rynkowego specyfikę (Lock, Harris, 1996, za: Cwalina, Falkowski, 2005, s. 20-23). Na potrzeby niniejszego tekstu przyjmuję, że marketing polityczny to „zespół teorii, metod, technik i praktyk społecznych, mających na celu przekonanie obywateli, by udzielili poparcia człowiekowi, grupie lub projektowi politycznemu" (Ulicka, 1996, s. 157). Jest to dość pojemna definicja, która pozwala traktować marketing polityczny jako proces komunikacyjny o celach perswazyjnych. Istotne jeszcze wydaje się podkreślenie, że proces ten dokonuje się poprzez orientację na obywateli, przejawiającej się w badaniu ich potrzeb i dostosowywania doń oferty (Wiszniowski, 2000, s. 17; Dobek-Ostrowska, Wiszniowski, 2002, s. 23). Chodzi tu nie tyle o potrzeby materialne, konsumpcyjne (a przynajmniej nie tylko o te), lecz o potrzeby wyższego rzędu, zaspokajane poprzez uczestnictwo w różnych formach wydarzeń i organizacji zbiorowych oraz budowanie relacji (Szromnik, 1996, s. 4-6). Jest to oczywiście tylko jedna z wielu konkurencyjnych definicji, w obrębie różnych paradygmatów myślenia o marketingu różnie rozkładających akcenty w definiowaniu jego istoty (por. Nowak, 2012, s. 37-42). 
W odniesieniu do marketingu, storytelling jest zbiorczą etykietą obejmującą techniki opowiadania historii (Wasilewski, Olczyk, 2017, s. 37), jest sposobem komunikowania idei przez narrację (Augustynowicz, 2016, s. 163). Jako narzędzie komunikacji rynkowej, pozwala w spójny i atrakcyjny sposób przedstawić określone fakty tak, by wyróżnić się na tle konkurencji i zostać zauważonym w morzu podobnych informacji. Komunikowanie treści w formie narracji, pozwala bowiem na skuteczniejsze zarządzanie wyobraźnią odbiorcy (Stopczyńska, 2016, s. 318; Mistewicz, 2011, s. 39, Stawnicka, 2014, s. 43-47). Storytelling, jako strategia menadżerska i komunikacyjna, narodził się w latach '90 w Stanach Zjednoczonych i stosunkowo szybko zyskał popularność jako narzędzie oddziaływania także w sferze politycznej (Loba, 2013, s. 70; Maarek, 2011, s. 26-28). Pablo Vasquez Sante łączy pojawienie się tego trendu $\mathrm{w}$ marketingu politycznym ze zjawiskiem personalizacji i prywatyzacji polityki. Personalizację rozumie jako zwiększony nacisk w kampaniach wyborczych na osobę kandydata, kosztem partyjnego logo czy programu. Natomiast prywatyzacja wiąże się z uczynieniem z osobistych, czy wręcz intymnych aspektów życia kandydata, głównego tematu przekazu marketingowego, przesuwające jego identyfikację partyjną na plan dalszy. W ten sposób przedstawiciele poszczególnych ugrupowań stanowią rodzaj skrótu poznawczego, za pomocą którego elektorat podejmuje decyzję o poparciu partii i jej programu. Taka zmiana w treści komunikowania wymusza również zmianę jego formatu, czyniąc narrację szczególnie efektywną w tym kontekście formą. Prezentowanie kandydatów poprzez ich osobiste historie czyni ich bardziej dostępnymi i wiarygodnymi, bardziej ludzkimi w oczach wyborców (2017, s. 276-277).

Zjawisko storytellingu zakorzenione jest w tradycji tzw. zwrotu narracyjnego, który z teorii literatury dość szybko zaczął promieniować na inne obszary humanistyki oraz nauki społeczne (Kohler Riessman, 1993, s. 4-6; Rosner, 2006, s. 5-13; Burzyńska 2004, 2008). Jedną z jego teoretycznych konsekwencji było podejście do narracyjności jako uniwersalnej formy ludzkiego doświadczenia i rozumienia rzeczywistości. Różni teoretycy posługują się w tym kontekście pojęciem struktury poznawczej lub trybu funkcjonowania umysłu, który porządkuje bodźce poznawcze w formę opowieści, organizujący poszczególne epizody i doświadczenia w sensowne i chronologicznie uporządkowane całości mające strukturę historii (Bruner, 1986; Trzebiński, 1992, 2002, 2004, 2008; Carr, 1991; Polkinghorne, 1988; Elliot, 2005; Gergen, Gergen, 1986). 
Łącząc sens obu pojęć można zdefiniować storytelling polityczny (polityczny marketing narracyjny) jako „technikę i/lub strategię marketingu politycznego, która uzyskuje efekt perswazyjny, w postaci politycznego poparcia dla idei, postaci lub organizacji, działania poprzez projektowanie komunikatu marketingowego na wzór opowiadania".

\section{Skuteczność storytellingu - aspekty formalne przekazu}

W publikacjach poświęconych storytellingowi, zwłaszcza tych przeznaczonych dla szerszego odbiorcy, często o bardziej podręcznikowoporadnikowym niż naukowym charakterze, zaobserwować można ogólny entuzjazm i zachwyt nad skutecznością tej strategii komunikacyjnej. Znacznie rzadziej natomiast obecny jest w nich pogłębiony namysł nad mechanizmami stojącymi za ową skutecznością i efektywnością. Autorzy prac poświęconych zagadnieniu, będący często również praktykami storytellingu, podkreślają, że treści przekazywane w sposób fabularyzowany, jako opowieść, nadają komunikatowi większą dystynktywność i siłę perswazyjną. Ma to wynikać z faktu, że narracyjny tryb myślenia, postrzeganie rzeczywistości w formie rozwijających się historii, jest naturalną, psychologiczną dyspozycją człowieka (Mistewicz, 2011, s. 38-45; Maxwell, Dickman, 2010, s. 15-18; Zubiel-Kasprowicz, 2016, s. 46). Przekonanie to wywodzą m.in. z ustaleń psychologów i badaczy komunikacji (takich jak np. Bruner, 1986; Fisher, 1987), choć w swych praktycznych radach wydają się bardziej podążać tropami wyznaczonymi przez lingwistów i teoretyków literatury (por. Labov, Waletzky, 1967; Barthes, 1977), traktujących narrację jako strukturę posiadającą pewne formalne właściwości. Uwzględnienie w komunikacji tych właśnie formalnych właściwości opowiadania ma stanowić o skuteczności w dotarciu do świadomości odbiorcy. Stąd też autorzy i autorki piszący o storytellingu częstokroć odwołują się do różnych wyobrażeń o uniwersaliach narracyjnej struktury (Tkaczyk, 2017; Maxwell, Dickman, 2010; Dening, 2005, 2007; Fog, Budtz, Yakaboylu, 2005; Stopczyńska, 2016; Augustynowicz, 2016; Visconti, 2016)ํ․

${ }^{1}$ Referowanie wszystkich (mniej lub bardziej różnych) poglądów w tej kwestii nie ma w kontekście niniejszego artykułu większego sensu. Nie jest bowiem moim celem weryfikowanie, który z modeli jest bardziej poprawny, ani analizowanie ich wad i zalet. Chodzi mi jedynie o zaznaczenie istniejącego trendu w rozumieniu i praktykowaniu storytellingu. Ponadto, referowanie całej gamy poglądów w tej kwestii znacznie przekroczyłoby objętość artykułu. 
Z perspektywy psychologicznej jest to $\mathrm{w}$ istocie uzasadnione podejście. Dobrze wyartykułowane elementy strukturalne narracji stanowią o jej spójności i w rezultacie funkcjonalności, jako umysłowego modelu danego fragmentu rzeczywistości. Ponadto dobrze skonstruowana narracja w większym stopniu angażuje uwagę, emocje i uczucia odbiorcy, a nawet zwiększa oddziaływanie perswazyjne komunikatu (Bruner, 2004; Trzebiński, 2004; Stemplewska-Żakowicz, Zalewski, 2010; Green, Brock, 2000; Green, 2004). Zresztą niektórzy teoretycy i praktycy odwołują się wprost do koncepcji psychologicznych (np. Wasilewski, 2017, s. 37-38; Maxwell, Dickman, 2010, s. 16-19), choć odwołania te mają raczej charakter dość powierzchowny.

Innym, często powracającym wątkiem w praktycznych wskazówkach dotyczących storytellingu, jest kwestia umocowania komunikatu w jakiejś bardziej uniwersalnej historii, ukazania jej na kanwie toposu stanowiącego ważną składową świadomości zbiorowej. Stąd pojawiają się odwołania do różnych archetypów i mitów, jako wzorców fabularnych przydatnych w konstruowaniu opowieści, czy też próby zredukowania wielości narracji do kilku uniwersalnych kulturowo typów (Zubiel-Kasprowicz, 2016; Hajdas, 2011; Denning, 2005; Świątecka, 2013; Simmons, 2007; Wasilewski, 2017). Zabieg taki umożliwia powiązanie indywidualnych historii z doświadczeniami wspólnymi całej zbiorowości, której jednostka jest częścią. Takie podejście również znajduje uzasadnienie w teoretycznych i empirycznych ustaleniach psychologów (Bruner, 1990, s. 50-52; Stemplewska-Żakowicz, 1997, s. 115).

Podsumowując, zarówno prace badaczy narracyjnych właściwości ludzkiego poznania i myślenia, jak również doświadczenia praktyków stosujących storytelling $\mathrm{w}$ ramach swych profesji, skłaniają do wniosku, że jest to skuteczna metoda perswazyjnego oddziaływania. Wyjaśniając mechanizm stojący za ową skutecznością, wskazać można na dwa tropy teoretyczne. Pierwszy odwołuje się do neuropsychologii, drugi zaś do odkryć psychologii poznawczej, zwłaszcza zaś badań nad właściwościami schematów poznawczych i niektórymi teoriami perswazji. Ten drugi wątek, jak postaram się wykazać w dalszej części niniejszego tekstu, nie jest w pełni wykorzystany w marketingu narracyjnym, a ma potencjalnie ogromne znaczenie dla jego skuteczności i efektywności.

Wracając zatem do postawionej wyżej kwestii, jaki mechanizm stoi za perswazyjną efektywnością storytellingu, dlaczego dobrze skomponowana historia porywa, przekonuje, angażuje, zostaje w pamięci? Po pierwsze, wyjaśnienia można szukać w neurofizjologicznym podłożu języka. 
Otóż w ludzkim mózgu istnieją dwa obszary odpowiedzialne za funkcje językowe, rozumienie i wytwarzanie komunikatów werbalnych. Są to okolica Broki i wzgórze Wernickego (Kurcz, 2000, s. 46-47). Podczas przetwarzania komunikatów językowych, odbierania ich i wytwarzania, te dwa obszary pozostają aktywne. Ich uszkodzenie natomiast skutkuje afazją, dysfunkcją w zakresie rozumienia bądź wytwarzania komunikatów językowych. Opowiadanie, tekst/komunikat językowy o specyficznej budowie strukturalnej, rzecz jasna angażuje pracę obu tych ośrodków. Jednocześnie jednak, w przeciwieństwie do nienarracyjnych form wypowiedzi, aktywuje również obszary mózgu regulujące inne funkcje i czynności organizmu - reakcje emocjonalne, ruch, doznania zmysłowe. Innymi słowy osoba słuchająca opowiadania, przeżywa je również na poziomie neuronalnym, doświadcza emocji, uczuć i bodźców, o których opowiadanie traktuje. Następuje sparowanie aktywności mózgu pomiędzy opowiadającą i słuchającą osobą (Stephens, Silbert, Hasson, 2010; Liu i in., 2017), za co odpowiedzialne wydają się być neurony lustrzane (Rizzolatti, Craighero, 2004; Bauer, 2008). Sugestywnie opowiedziana historia, o klarownej fabule, wyrazistych bohaterach, ich obrazowo przedstawionych doświadczeniach i zmaganiach, pozwala ją nie tylko usłyszeć poczuć, przeżyć, lecz na poziomie neurofizjologicznym poniekąd osobiście doświadczyć. Osobiste przeżycia są zaś zawsze bardziej wyraziste i trwalej zapadają w pamięć. Dlatego storytelling nie jest tylko komunikowaniem treści, informowaniem o faktach. Dystynktywność i sugestywność przekazywanych narracyjnie treści wynika z tego, że ,opowiadanie jest to fakt opakowany w emocje, które skłania nas do podjęcia działania przekształcającego świat" (Maxwell, Dickman, 2010, s. 16; por. Fog, Budtz, Yakaboylu, 2005, s. 19-22). Storytelling angażuje więc nie tylko (może nawet nie przede wszystkim) intelekt, lecz także uczucia i emocje.

W świetle powyższego, aby poprzez storytelling skutecznie i efektywnie przekonać do swoich idei, aby przekazać odbiorcom treści, na których nam zależy, należy stworzyć sugestywne opowiadanie według określonego przepisu. Architektura takiego tworu musi zawierać określone elementy, które odpowiednio skomponowane wzbudzą emocjonalny rezonans w odbiorcy i pozyskają go dla opowiadanej sprawy. W tej perspektywie cała tajemnica storytellingu opiera się na skonstruowaniu przekazu według określonego schematu, swoistego narracyjnego opakowania dla określonej idei, osoby, organizacji, zjawiska. Intuicja i naukowy sceptycyzm podpowiadają jednak, że sprawa jest nieco bardziej skomplikowa- 
na. Jak zauważa bowiem Francesca Poletta (2008, s. 29), ,to co się liczy to nie tyle sama opowieść, lecz sposób w jaki rezonuje ona $\mathrm{z}$ opowieściami, które publiczności są już znane" (Poletta, 2008, s. 29; por. Maccozzo, Green, Brock, 2007). Słowa amerykańskiej badaczki wskazują na jeszcze inny, obok formalnych cech przekazu, istotny czynnik determinujący skuteczność storytellingu. Chodzi mianowicie o relację pomiędzy samym przekazem a jego odbiorcą, kształtowany m.in. już posiadanymi zasobami narracyjnymi podmiotu.

\section{Skuteczność storytellingu - przesłanki psychologiczne}

Założenie, że klucz do skutecznego storytellingu leży w poprawnym skonstruowaniu narracji i osadzeniu jej na kanwie uniwersalnych w danej zbiorowości narracyjnych toposów, oznacza de facto przyjęcie modelu biernego poznawczo odbiorcy. Tymczasem, o czym więcej poniżej, rzecz ma się zgoła inaczej. Przytaczane wyżej koncepcje storytellingu wydają się koncentrować na tym, co w komunikacyjnym modelu Jakobsona określane jest jako poetycki lub estetyczny aspekt komunikatu. Natomiast $\mathrm{w}$ dalszych partiach niniejszego artykułu, nacisk zostanie położony na funkcję konatywną, opisującą stosunki zachodzące między komunikatem i jego odbiorcą, w tym reakcje adresata na przekaz (por. DobekOstrowska, 2002, s. 98-99).

Z dotychczasowych rozważań wynika, że skuteczny przekaz storytellingowy musi być skonstruowany w określony sposób, będący w stanie pobudzić odpowiedzialny za emocje układ limbiczny odbiorcy, angażując $\mathrm{w}$ ten sposób jego uwagę. Jest to również warunek skuteczności perswazyjnej takiego komunikatu. Jednakże jest pewna bariera w tym procesie, której teoretycy storytellingu wydają się nie dostrzegać. Otóż adresat komunikatu nie jest $\mathrm{w}$ procesie komunikowania biernym odbiorcą, lecz aktywnym poznawczo podmiotem. Aktywność ta związana jest ze specyfiką ludzkiego poznania, która ma charakter konstrukcyjny. To oznacza, że odbierane z otoczenia bodźce nie odbijają się w sposób bezpośredni w ludzkiej świadomości, lecz są przez podmiot przetwarzane poznawczo. Ta konstruktywna aktywność umysłu sprawia, że ludzkie poznanie ma charakter interpretacyjny, polega na tworzeniu reprezentacji poznawczych rzeczywistości, których treść odbiega od obiektywnych właściwości bodźca, a wiąże się z przyjmowaniem pewnej postawy psychicznej wobec niego (Nęcka, Orzechowski, Szymura, 2008, s. 23-29; 
Wojciszke, Doliński, 2008, s. 295; Kozielecki, 2000, s. 213; Trzebiński, 2002, s. 17-21; Bobryk, 1997, s. 53). Konsekwencją takiego stanu rzeczy jest to, że nawet najlepiej skonstruowana narracja marketingowa, która zyskuje uwagę i zainteresowanie odbiorcy, nie powoduje u niego automatycznej zmiany przekonań, postaw czy zachowania, w pożądanym przez nadawcę kierunku. Intencja i cele komunikacyjne nadawcy nie odciskają się bowiem automatycznie w umyśle odbiorcy, lecz są przez niego przetwarzane $\mathrm{i}$ interpretowane.

To, czy dana informacja zostanie włączona w system przekonań jednostki zależy m.in. od już posiadanych przez nią przekonań. Zgodnie z modelem poznawczych reakcji na perswazję (Greenwald, 1968), zawarte w komunikacie treści zostają odniesione do istniejących już postaw, przekonań i uczuć związanych z przedmiotem komunikatu. Ich wzbudzenie powoduje, że dany komunikat rozpatrywany jest jako zgodny, bądź nie z posiadaną wiedzą i w rezultacie może być albo zaakceptowany, albo odrzucony (Gilbert, Fiske, Lindzey, 2009, s. 332-334; Zimbardo, Leippe, 2103, s. 149-152). Aby pokonać tę barierę i zwiększyć efektywność perswazji, należy wobec tego uwzględnić w konstrukcji marketingowej narracji stan wiedzy i uczuć odbiorców.

Teoretycznych narzędzi, pozwalających się zmierzyć z tym problemem, dostarcza formułowana w psychologii nurtu poznawczego koncepcja schematów poznawczych. Schemat poznawczy to struktura umysłowa, stanowiąca podstawowy element strukturalny wiedzy o świecie. Zawiera on uogólnioną wiedzę na temat danego wycinka rzeczywistości, wyznaczając sposób spostrzegania, myślenia i działania. Nie jest jednak wierną kopią tej rzeczywistości, lecz jej idealizacją, reprezentującą jej zasadnicze elementy i właściwości. W schemacie zawarta jest nie tylko deskryptywna informacja o obiekcie, lecz także wiedza jednostki o własnych nań reakcjach. To oznacza, że w schemacie zostają zakodowane również emocje podmiotu przeżywane $\mathrm{w}$ kontakcie $\mathrm{z}$ egzemplarzami schematu. Umożliwiają one człowiekowi szybką reakcję na sytuację bodźcową na bazie wcześniej ukształtowanej wiedzy o świecie (Wojciszke, 1986, s. 16-17; Trzebiński, 1985, s. 264-267; Nęcka, Orzechowski, Szymura, 2008, s. 131-132). Schemat funkcjonuje jako identyfikator, koder, interpretator i rezonator emocjonalny wobec informacji bodźcowej. Oznacza to m.in., że porównując ją z treściami zawartymi w już obecnym schemacie determinuje to jak informacja ta zostanie zrozumiana i jaki oddźwięk emocjonalny wzbudzi (Wojciszke, 1985, s. 51-52). Zatem to czy komunikat wprowadzi w pole świadomości odbiorcy treści, jakie 
nadawca zamierzył, zależy od tego czy i na ile jest on spójny ze schematami poznawczymi odbiorcy. Ponieważ „zrozumienie jakiegoś fragmentu rzeczywistości - to znalezienie takiego schematu poznawczego, którego ten fragment jest szczególnym przypadkiem" (Trzebiński, 1985, s. 282), to w perspektywie poznawczych reakcji na perswazję, cała sztuka polega na tym by aktywować u odbiorcy właściwe schematy poznawcze.

Powyższe rozważania są o tyle istotne, że narracja w perspektywie psychologii poznawczej, rozumiana jest jako specyficzny rodzaj schematu poznawczego. Jest to podstawowy schemat reprezentujący świat ludzi i ich działania, również grup oraz bytów antropomorficznych. Ma budowę skryptową, co oznacza, że zawiera informacje o zdarzeniach i działaniach społecznych i ich aktorach. Zawiera informacje o bohaterach zdarzeń, ich wartościach i intencjach oraz towarzyszących planach realizacji tychże, występujących komplikacjach oraz uwarunkowaniach i szansach ich przezwyciężenia (Trzebiński, 1992, s. 25; Trzebiński, 1983, s. 12; Trzebiński, 2002, s. 23). Schemat narracyjny danej sfery życia społecznego (np. polityki) wiąże poszczególne elementy (np. politycy, obywatele, elity, partie, instytucje, grupy nacisku) w formie relacji, które mają postać wzajemnych uwarunkowań realizacji celów (Trzebiński, 1983, s. 12-15).

\section{Dedykowany storytelling, czyli jak to zrobić lepiej}

Powyższe uwagi pozwalają na sformułowanie dyrektywy odnośnie praktycznych aspektów storytellingu. Dobra narracja polityczna (lub inna) powinna po pierwsze korespondować z strukturalnymi właściwościami schematu narracyjnego (por. Wasilewski, Olczyk, 2017). Można więc powyższe ustalenia teoretyczne potraktować jako kolejną propozycję storytellingu opartą o zasadę budowy formalnie poprawnego przekazu narracyjnego. Jednakże biorąc pod uwagę zasadę hierarchiczności budowy schematów okazuje się, że opowieść może zostać skonstruowana precyzyjniej. Oprócz skomponowania narracji analogicznie do budowy schematu narracyjnego, możliwe jest również zadbanie o to, aby poszczególne składowe schematu narracyjnego (subschematy w ramach metatematu) zostały skonstruowane tak by zminimalizować negatywne reakcje poznawcze odbiorcy. Innymi słowy, chodzi tu o taką kompozycję narracji, której budowa będzie przypominać schematy już posiadane przez adresatów komunikatu. Istota tego zabiegu stanie się czytelniejsza jeśli zostanie rozważona na przykładach. 
Jeśli jakaś grupa odbiorców postrzega politykę jako pole działania zakulisowych sił, które manipulują społeczeństwem w celu realizacji swoich niecnych zamierzeń, to siłą rzeczy nie będzie dla niej przekonujący przekaz określonej partii, wedle którego polityka to przestrzeń, gdzie świadomi i wolni obywatele, wykuwają wspólnie treść polityki, w przejrzystych procedurach opartych na dialogu i negocjacjach wzajemnie rozbieżnych interesów. W takim wypadku nie tylko cały metatemat (polityka) ma zasadniczo inną treść, ale również subschematy takich narracji (np. aktorzy) są całkowicie odmienne. $Z$ jednej strony postaci tej opowieści to ukryte, potężne, anonimowe siły, z drugiej zaś świadomi i wolni obywatele. Osoby przekonane do takiej spiskowej interpretacji polityki, czyli posiadające określony schemat tej sfery życia społecznego, posłużą się nim jako identyfikatorem wobec owego idyllicznego przekazu. Już posiadana narracja o polityce (spisek) spowoduje, że jej opis jako przejrzystego pola działania wolnych obywateli nie zostanie zinterpretowany jako opis polityki, lecz jako coś zgoła innego, choćby propaganda owych ukrytych sił, mająca manipulować społeczeństwem. To oczywiście rodzi określone reakcje emocjonalne i postawy wobec przekazu. Odwołując się modelu poznawczych reakcji na perswazję, można powiedzieć, że niespójność przekazu z już posiadanymi przekonaniami, wzbudziła negatywne reakcje poznawcze i poskutkowała jego odrzuceniem. Z powyższego przykładu wynika, że storytelling projektowany jedynie w oparciu o formalne właściwości opowiadania, a nieuwzględniający reakcji poznawczych odbiorców, ma ograniczone możliwości działania. Sytuacja powyższa jest oczywiście przykładem skrajnym. Każdy teoretyk i praktyk marketingu wie, że są segmenty społeczne, których poparcie dla określonych idei, osób czy organizacji jest w zasadzie niewzruszone, a możliwość oddziaływania na nie znikoma. Można powiedzieć, że są to w istocie tak silnie rozbieżne narracje, że żadna marketingowa opowieść - nawet skonstruowana tak dobrze, że zasługiwałaby na literackiego Nobla - nie podziała. Opis metatematu i jego poszczególnych subschematów, jest bowiem skrajnie niekoherentny z posiadanymi przekonaniami i postawami, wobec czego wzbudza skrajnie negatywne reakcje poznawcze. Przykładem takich skrajnie rozbieżnych narracji, pomiędzy którymi wydaje się nie być punktów stycznych, są opowieści medialne snute wokół sporu o Trybunał Konstytucyjny (por. Bachryj-Krzywaźnia, 2017).

2 Takie wykrystalizowanie przekonania mogą oczywiście dotyczyć również poszczególnych aspektów życia politycznego, pojedynczych procesów, zdarzeń lub podmiotów. 
Możliwe są jednak inne, mniej skrajne okoliczności, w których istnieje większe pole manewru. Może przykładowo zaistnieć sytuacja, w której w określonym segmencie społecznym nie funkcjonuje spójna narracja o polityce, czy jakiejś konkretnej kwestii, zdarzeniu lub procesie. W takich warunkach, znając treść i budowę schematów, które mogą stać się składowymi narracji, za pomocą storytellingu możliwe jest zaproponowanie takiej opowieść, która będąc z nimi spójna, zredukuje prawdopodobieństwo negatywnych reakcji poznawczych, a przy tym zepnie już posiadane przekonania i postawy w spójną całość. Jeżeli zostanie ona poprawnie zbudowana i zinternalizowana przez odbiorców jako schemat narracyjny, będzie jednocześnie wzbudzać negatywne reakcje poznawcze na komunikat perswazyjny podważający zawarte w niej treści. Ponadto jeszcze przynosi odbiorcy psychologiczny zysk w postaci zaspokojenia potrzeby domknięcia poznawczego i redukuje poczucie poznawczej niepewności (Webster, Kruglanski, 1994; Kruglanski, Webster, 1996).

Sytuacja trzecia to taka, w której dana grupa posiada już ukształtowaną narrację, jednakże ma ona pewne punkty styczne z opowieścią komunikowaną w przekazie marketingowym. Może to dotyczyć zarówno całego metatematu, jak i jego poszczególnych subschematów. Owe punkty styczne można wykorzystać w ten sposób, że zostaną wplecione w fabułę storytellingowego przekazu tak, by zminimalizować ryzyko zaistnienia negatywnych reakcji poznawczych i w ten sposób pozwolą pozyskać odbiorców dla konkurencyjnej wobec już posiadanej przezeń opowieści.

\section{Segmentacja na potrzeby dedykowanego storytellingu}

Powyższe zabiegi wymagają oczywiście zdiagnozowania treści i typów narracji w poszczególnych grupach odbiorców. Skuteczna strategia storytellingowa powinna z jednej strony przekazywać spójną opowieść, z drugiej zaś posiadać pewien wachlarz wariantów tejże, tak aby przekaz do konkretnych grup odbiorców mógł być precyzyjniej dedykowany. Konieczna jest zatem swoista segmentacja, której istotą będzie podział całości potencjalnych odbiorców na wspólnoty narracyjne. Jak twierdzą Trzebiński i Drogosz, „treść narracji i autonarracji konstruowanych przez jednostkę nie tylko jest w swych ogólnych elementach powtarzalna, ale ma również wspólne lub komplementarne cechy z narracjami i autonarracjami ludzi zajmujących podobną pozycję w strukturze społecznej, a także ludzi, na których oddziałuje ta sama kultura [...]. Wspólnota narracyjnej 
wiedzy wynika nie tylko z pozostawania pod wpływem tej samej kultury, ale też wspólnoty doświadczeń" (2005, s. 151-152). Co więcej, treść narracji i autonarracji, wykazuje związki z preferencjami politycznymi i postawami wobec różnych kwestii społecznych (Drogosz, Trzebiński, Zięba, 2005). Można zatem oczekiwać, że cechy i typy narracji będą korelować z różnymi zmiennymi socjologicznymi, demograficznymi, czy psychologicznymi, co z kolei umożliwia dość precyzyjną segmentację. Poszczególne segmenty reprezentowałyby różne typy narracji, to znaczy różniące się pod względem treści jak również tego kogo i/lub co obsadzają w poszczególnych rolach schematu narracyjnego. Można zatem teoretycznie wyróżnić narracje progresywne i regresywne, proaktywne i defensywne. Pojawiający się w nich bohaterowie mogą być jednostkami lub bytami kolektywnymi (naród), motywowanymi wewnętrznie (strach, nadzieja, kodeks moralny) lub zewnętrznie (nakaz boski, konieczność historyczna, potrzeba narodu, ojczyzny, lub innej zbiorowości, której jest częścią), mieć charakter realny lub transcendentny (bóg i szatan), osobowy lub bezosobowy (instytucja). Napotykane komplikacje mogą z kolei mieć charakter czyichś działań intencjonalnych lub niefortunnego zbiegu przypadków, mogą mieć charakter osobowy i bezosobowy, subiektywny i obiektywny.

Zestawiając ze sobą różnorodność narracji i polimorficzność jej poszczególnych składowych (subschematów) można uzyskać całą gamę konfiguracji różnych zmiennych definiujących określony typ narracji. Nie można ponadto wykluczyć, że jej poszczególne składowe mają różną wagę, co dodatkowo komplikuje obraz. Z pewnością jednak możliwa jest rekonstrukcja narracji określonej grupy (lub jednostki) w odniesieniu do wybranej sfery życia społeczno-politycznego lub pojedynczej kwestii, zdarzenia, procesu. Informacje te pozyskać można na co najmniej kilka sposobów. Przydatne będą z pewnością metody jakościowe takie jak wywiad pogłębiony (zwłaszcza narracyjnie zorientowany), zogniskowany wywiad grupowy, czy też różne techniki projekcyjne. Możliwe jest także zastosowanie metody kwestionariuszowej (por. Trzebiński, Drogosz, 2005; Drogosz, Trzebiński, Zięba, 2005). Analiza zawartości, zwłaszcza jej wersja jakościowa, pozwala natomiast wykorzystać w tym celu dane zastane - wypowiedzi utrwalone w formie cyfrowej lub drukowanej (np. prasa, media społecznościowe). W analogiczny sposób można wykorzystać do tego celu różne metody analizy dyskursu (np. Bachryj-Krzywaźnia, 2016, 2017). Nie jest to z pewnością zamknięty katalog metod i strategii badawczych. W zasadzie każda intepretacjonistyczna metoda 
i technika badawcza, umożliwiająca rekonstrukcję subiektywnego obrazu rzeczywistości, może okazać się w takiej narracyjnej segmentacji użyteczna.

\section{Zakończenie}

W świetle badań i teorii psychologicznych, językoznawczych, czy semiotycznych, narracyjne myślenie i doświadczanie rzeczywistości jest uniwersalną i naturalną dyspozycją ludzkiego gatunku. Na tym opiera się skuteczność storytellingu. Jednakże, aby w pełni wykorzystać drzemiący w tej metodzie potencjał oddziaływania na odbiorców, nie wystarczy sama fabularyzacja przekazu. Konieczne jest zbadanie treści i specyficznych cech strukturalnych zasobów narracyjnych poszczególnych grup odbiorców. Zidentyfikowanie w ten sposób stylów narracyjnych poszczególnych segmentów odbiorców, umożliwi w rezultacie dopasowanie do nich komunikatu narracyjnego w taki sposób, aby nie wzbudzał on negatywnych reakcji poznawczych. Istotne jest bowiem to, żeby poszczególne elementy strukturalne proponowanej narracji, korespondowały z treściami i strukturalnymi cechami przekonań odbiorców, zorganizowanych $\mathrm{w}$ formie schematów poznawczych. Innymi słowy, przekaz narracyjny nie może być konstruowany w oderwaniu od sposobu poznawczego funkcjonowania potencjalnego odbiorcy. Treść jego przekonan, sposób ich zorganizowania, psychologiczne aspekty procesów poznawczych, stanowią istotny czynnik determinujący efektywność storytellingu. Byłoby to w zasadzie trywialne twierdzenie gdyby nie fakt, że w przywoływanych w pierwszej części niniejszego artykułu modelach storytellingu, jest to kwestia w zasadzie nieobecna. Koncentrują się one bowiem na tym jak opowiadać, jak konstruować historię, podczas gdy równie istotną kwestią jest to do kogo kierowana jest opowieść. Uwzględnienie tych dwóch elementów równania, wedle zaproponowanego tu modelu, zwiększa efektywność oddziaływania narracyjnie zorganizowanej komunikacji.

Ujmując rzecz nieco prostszym, metaforycznym i trochę publicystycznym językiem. By porwać słuchacza historią należy zadbać również o to by był to ten typ opowieści, który akurat dla tych odbiorców jest atrakcyjny, aby opowiadała o bohaterach, którzy dla tych konkretnych odbiorców kreowani są w sposób przekonujący, należy zwrócić uwagę na to, aby opowieści te były podobne do życia, tak jak subiektywnie postrzegają je ich odbiorcy. Każdy lubi słuchać opowieści, jednak gdy jedni 
kochają melodramaty, inni preferują komedie, a jeszcze kolejni fabuły przygodowe, wojenne, szpiegowskie, katastroficzne. Nie dla każdego ten sam typ opowieści będzie pociągający. Co więcej, różni odbiorcy lubią też różnych bohaterów - od tych nieskazitelnych i nieugiętych, przez bardziej przypominających zwykłych ludzi, po tych całkiem niejednoznacznych i ułomnych. Storytelling, aby być skuteczną metodą oddziaływania na odbiorcę, musi nie tylko dobrze konstruować opowieści, lecz musi także zadbać o to, by poszczególnym odbiorcom dedykować takie rodzaje fabuł, jakich lubią słuchać, o takich bohaterach i zdarzeniach, które ich faktycznie pociągają, są bliskie ich subiektywnemu doświadczeniu.

\section{Bibliografia}

Augustynowicz C. (2016), Uwagi o storytellingu jako strategicznej koncepcji brandingu $i$ operacyjnego narzędzia komunikacji, „Zbliżenia Cywilizacyjne”, vol. $12, \mathrm{nr} 1$.

Bachryj-Krzywaźnia M. (2016), ,, Byt sobie gender ...”. Kategoria gender w dyskursie „Gościa Niedzielnego" - analiza pola semantycznego i analiza aktantowa, „Politeja”, vol. 43, nr 4.

Bachryj-Krzywaźnia M. (2017), W stronę despotii czy normalności? Medialne narracje wokót sporu o Trybunat Konstytucyjny, w: Pomiędzy mythos i logos spotecznej zmiany, red. J. Golinowski, S. Sadowski, Wydawnictwo Uniwersytetu Kazimierza Wielkiego, Bydgoszcz.

Barthes R. (1977), Image, Music, Text, Fontana Press, London.

Bauer J. (2008), Empatia: co potrafia neurony lustrzane, Wydawnictwo Naukowe PWN, Warszawa.

Bobryk J. (1997), Teoretyczny punkt wyjścia: czynności spostrzegania i interpretowania, wytwory tych czynności, decyzje psychiczne je determinujace, w: Percepcja i interpretacja spolecznej i politycznej sytuacji w Polsce, red. I. Kurcz, J. Bobryk, Wydawnictwo Instytutu Psychologii PAN, Warszawa.

Bruner J. (1986), Actual Minds, Possible Worlds, Harvard University Press, Cambridge-London.

Bruner J. (1990), The Acts of Meaning, Harvard University Press, Cambridge-London.

Bruner J. (2004), Life as Narrative, „Social Research”, vol. 71, nr 3.

Burzyńska A. (2004), Kariera narracji. O zwrocie narratywistycznym w humanistyce, „Teksty Drugie”, nr 1/2.

Burzyńska A. (2008), Idea narracyjności w humanistyce, w: Narracja. Teoria i praktyka, red. B. Janusz, K. Gdowska, B. de Barbaro, Wydawnictwo Uniwersytetu Jagiellońskiego, Kraków.

Carr D. (1991), Time, Narrative and History, Indiana University Press, BloomingtonIndianapolis. 
Cwalina W., Falkowski A. (2005), Marketing polityczny. Perspektywa psychologiczna, Gdańskie Wydawnictwo Psychologiczne, Gdańsk.

Denning S. (2005), Leader's Guide to Storytelling, John Wiley \& Sons, Inc., San Francisco.

Denning S. (2007), The Secret Language of Leadership, John Wiley \& Sons, Inc., San Francisco.

Dobek-Ostrowska B. (2002), Podstawy komunikowania społecznego, Wydawnictwo Astrum, Wrocław.

Dobek-Ostrowska B., Wiszniowski R. (2002), Teoria komunikowania publicznego i politycznego. Wprowadzenie, Wydawnictwo Astrum, Wrocław.

Drogosz M., Trzebiński J., Zięba M. (2005), Styl autonarracji i poziom nadziei podstawowej a postawy spoleczne Polaków, w: Demokracja w Polsce. Doświadczanie zmian, red. U. Jakubowska, K. Skarżyńska, Academica Wydawnictwo SWPS, Warszawa.

Elliot J. (2005), Using Narrative in Social Research: Qualitative and Quantitative Approaches, Sage Publications, London-Thousand Oaks-New Delhi.

Fisher W. R. (1987), Human Communication as Narration: Toward a Philosophy of Reason, Value, and Action, University of South Carolina Press, Columbia.

Fog K., Christian B., Yakaboylu B. (2005), Storytelling. Branding in Practice, Springer, Copenhagen.

Gergen J. J., Gergen M. M. (1986), Narrative Form and Construction of Psychological Science, w: Narrative Psychology: The Storied Nature of Human Conduct, red. T. R. Sarbin, Preager, Westport-London.

Gilbert D. T, Fiske S. T, Lindzey G. (2009), The Handbook of Social Psychology, vol. 1, McGraw-Hill Companies, Inc., Boston.

Green M. C. (2004), Transportation into Narrative Worlds: The Role of Prior Knowledge and Perceived Realism, ,Discourse Processes”, vol. 38, nr 2.

Green M. C., Brock T. (2000), The Role of Transportation in the Persuasiveness of Public Narratives, ,Journal of Personality \& Social Psychology”, vol. 79, nr 5.

Greenwald A. (1968), Cognitive Learning, Cognitive Response to Persuasion and Attitude Change, w: Psychological Foundations of Attitudes, red. A. Greenwald, T. Brock, T. Ostrom, Academic Press, New York.

Hajdas M. (2011), Storytelling - nowa koncepcja budowania wizerunku marki w epoce kreatywnej, „Współczesne Zarządzanie”, nr 1.

Kohler Riessman C. (1993), Narrative Analysis, Sage Publications, Newbury ParkLondon-New Delhi.

Kozielecki J. (2000), Koncepcje psychologiczne człowieka, Wydawnictwo Akademickie ,Żak”, Warszawa.

Kruglanski A. W., Webster D. M. (1996), Motivated closing of the mind: Seizing and Freezing, „Psychological Review”, vol. 103, nr 2.

Kurcz I. (2000), Psychologia języka i komunikacji, Wydawnictwo Naukowe SCHOLAR, Warszawa. 
Labov W., Waletzky J. (1967), Narrative analysis: oral versions of personal experience, w: Essays on the verbal and visual arts, red. J. Helm, University of Washington Press, Seattle.

Liu Y., et al. (2017), Measuring speaker-listener neural coupling with functional near infrared spectroscopy, https:/www.nature.com/articles/srep43293.pdf, 23.05.2018.

Loba M. (2013), Wokót narracyjnego zwrotu. Szkice krytyczne, Wydawnictwo Naukowe UAM, Poznań.

Lock A., Harris P. (1996), Political marketing - vive la difference!, „European Journal of Marketing", vol. 30, nr 10/11.

Maarek P. J. (2011), Campaign Communication and Political Marketing, WilleyBlakwell, Malden.

Maccozzo P. J., Green M. C., Brock T. C. (2007), The Effects of a Prior Story-Bank on the Processing of a Related Narrative, „Media Psychology”, vol. 10, nr 1.

Maxwell R., Dickman R. (2010), Elementy perswazji. Historie wnikajace w umyst. Sprzedawanie i motywowanie przez opowiadanie, MT Biznes, Warszawa.

Mazur M. (2004), Marketing polityczny. Studium porównawcze, Wydawnictwo Naukowe PWN, Warszawa.

Mistewicz E. (2011), Marketing narracyjny. Jak budować historie, które sprzedaja, Helion, Gliwice.

Nęcka E., Orzechowski J., Szymura B. (2008), Psychologia poznawcza, Academica Wydawnictwo SWPS, Wydawnictwo Naukowe PWN, Warszawa.

Nowak E. (2012), Marketing polityczny jako dyscyplina naukowa, „Studia Politologiczne", vol. 24.

Poletta F. (2008), Storytelling in politics, „Contexts”, vol. 7, nr 4.

Polkinghorne D. E. (1988), Narrative Knowing and the Human Sciences, State University of New York Press, Albany.

Rizzolatti G., Craighero L. (2004), The Mirror-Neuron System, „Annual Review of Neuroscience", vol. 27, nr 1, s. 169-192.

Rosner K. (2006), Narracja, tożsamość, czas, Universitas, Kraków.

Simmons A. (2007), Whoever Tells the Best Story Wins, AMACOM, New York.

Stawnicka J. (2014), Strategia marketingu narracyjnego w Policji. Nowoczesny wymiar kreowania wizerunku, Wydawnictwo Naukowe Wyższej Szkoły Biznesu w Dąbrowie Górniczej, Dąbrowa Górnicza.

Stemplewska-Żakowicz K. (1997), Wpływ kulturowych wzorców narracyjnych na poznawcza reprezentację rzeczywistości społecznej i osobistych doświadczeń społecznych, w: Percepcja i interpretacja społecznej i politycznej sytuacji w Polsce, red. I. Kurcz, J. Bobryk, Wydawnictwo Instytutu Psychologii PAN, Warszawa.

Stemplewska-Żakowicz K., Zalewski B. (2010), Czym jest dobra narracja? Struktura narracji z perspektywy badaczy $i$ klinicystów, w: Badania narracyjne $w$ psychologii, red. M. Straś-Romanowska, B. Bartosz, M. Żurko, Wydawnictwo Eneteia, Warszawa. 
Stephens G. J., Silbert L. J., Hasson U. (2010), Speaker-listener neural coupling underlies successful communication, „Proceedeings of the National Academy of Science of the United States", vol. 107, nr 32.

Stopczyńska K. (2016), Wykorzystanie storytelling $w$ kreowaniu wizerunku marki w social media, „Handel Wewnętrzny” vol. 62, nr 3.

Szromnik A. (1996), Marketing komunalny. Rynkowa koncepcja zarządzania gmina, „Samorząd Terytorialny”, vol. 63, nr 3.

Świątecka A. (2013), Digital storytelling. Podręcznik dla edukatorów, Fundacja Ad Hoc, Warszawa.

Tkaczyk P. (2017), Narratologia, Wydawnictwo PWN, Warszawa.

Trzebiński J. (1983), Reprezentacje skryptopodobne jako formy , ukrytych teorii osobowości”, w: Poznawcze regulatory funkcjonowania społecznego, red. J. Jarymowicz, Z. Smoleńska, Ossolineum, Wydawnictwo PAN, Wrocław-Warszawa-Kraków-Gdańsk-Łódź.

Trzebiński J. (1985), Rola schematów poznawczych w zachowaniach społecznych, w: Psychologia spostrzegania społecznego, red. M. Lewicka, J. Trzebiński, Książka i Wiedza, Warszawa.

Trzebiński J. (1992), Narracyjne formy wiedzy potocznej, Wydawnictwo Nakom, Poznań.

Trzebiński J. (2004), Narracyjne doświadczenie i narracyjna refleksja, w: Samoświadomość i jakość życia. Perspektywa psychospołeczna, red. L. Pytka, T. Rudowski, Wydawnictwo Psychologii i Kultury ENETEIA, Warszawa.

Trzebiński J. (2004), Wpływa dynamiki epizodów i klarowności wątku na sitę oddziatywania historii, w: Narracyjność języka i kultury, red. D. Filar, D. Piekarczyk, Wydawnictwo UMCS, Lublin.

Trzebiński J. (2008), Problematyka narracji we współczesnej psychologii, w: Narracja. Teoria i praktyka, red. B. Janusz, K. Gdowska, B. de Barbaro, Wydawnictwo Uniwersytetu Jagiellońskiego, Kraków.

Trzebiński J. (2002), Narracyjne konstruowanie rzeczywistości, w: Narracja jako sposób rozumienia świata, red. J. Trzebiński, Gdańskie Wydawnictwo Psychologiczne, Gdańsk.

Trzebiński J., Drogosz M. (2005), Historie, które kształtują nasze życie: O konsekwencjach proaktywnych i defensywnych autonarracji, w: Jak Polacy wygrywaja, jak Polacy przegrywają?, red. M. Drogosz, Gdańskie Wydawnictwo Psychologiczne, Gdańsk.

Ulicka G. (1996), Wplyw marketingu politycznego na zmiany $w$ życiu publicznym państw demokratycznych, ,Studia Politologiczne”, vol. 1.

Vazques Sande P. (2017), Personalization of politics, storytelling and conveyed values, „Communication and Society”, vol. 30, nr 3.

Visconti L. M. (2016), A conversational approach to consumer vulnerability: performativity, representations, and storytelling, „Journal of Marketing Management", vol. 32, nr 3-4. 
Wasilewski J., Olczyk T. (2017), Storytelling jako narzędzie marketingu politycznego - model, „Studia Politologiczne”, vol. 45.

Webster D. M., Kruglanski A. W. (1994), Individual differences in need for cognitive closure, „Journal of Personality and Social Psychology”, vol. 67, nr 6.

Wiszniowski R. (2000), Marketing wyborczy, Wydawnictwo PWN, Warszawa.

Wiszniowski R. (2002), Wprowadzenie do teorii marketing politycznego, w: Marketing polityczny $w$ teorii i praktyce, red. A. W. Jabłoński, L. Sobkowiak, Wydawnictwo Uniwersytetu Wrocławskiego, Wrocław.

Wojciszke B. (1986), Teoria schematów społecznych. Struktura i funkcjonowanie jednostkowej wiedzy o otoczeniu społecznym, Ossolineum, Wydawnictwo PAN, Wrocław-Warszawa-Kraków-Gdańsk.

Wojciszke B., Doliński D. (2008), Psychologia społeczna, w: Psychologia. Podręcznik akademicki, t. 2, red. D. Doliński, J. Strelau, Gdańskie Wydawnictwo Psychologiczne, Gdańsk.

Zimbardo P. G., Leippe M. R (2013), The Psychology of Attitude Change and Social Influence, McGrew Hill, Boston.

Zubiel-Kasprowicz M. (2016), Storytelling as modern architecture of narration in marketing communication, „Torun Business Review”, vol. 15, nr 1.

\section{Dedicated storytelling - psychological premises of narrative political marketing's persuasive effectiveness}

\section{Summary}

Abstract: Theoreticians and practitioners of storytelling usually focus on the formal quality of the message, seeing the key to its persuasive effectiveness in fulfilling the structural features of the story. This very article, on the other hand, put emphasize on cognitive aspect of message-recipient relation, as an important factor affecting the strength of storytelling's persuasive influence. In the first section, the paper discuss psychological premises of persuasive qualities of narrative message. The following section is a theoretical proposition how to increase its effectiveness by taking into account the structure, properties and functions of cognitive schemata and on the strength of the cognitive response model of persuasion.

Key words: storytelling; narrative marketing; political marketing; persuasion 